\title{
ICT Governance versus Community Empowerment: Grassroots Evidence from Bangladesh
}

\author{
Mizanur Rahman \\ Development Research Network, Bangladesh, \\ 6/8 Humayun Road, Block B, Mohammadpur, Dhaka 1207, Bangladesh \\ mizanur.rahman@dnet.org.bd
}

\begin{abstract}
Information and Communication Technologies (ICT) is a catalyst to enhance the level of community empowerment - with this motivation, this paper reports on a research study on "Community Empowerment Through ICTs: Evidence from Grassroots in Bangladesh and India". The evidence from an early benchmark study from Bangladesh shows that ICT penetration on its own is not proportionately related with community empowerment. Rather, ICT penetration with a precise application of ICT governance, strengthens community empowerment. The evidence also shows that if ICT penetration is high, but ICT governance is low, ICT does not remain as high a catalytic factor for community empowerment.
\end{abstract}

Keywords: ICT Governance, ICT Penetration, Ethics of Computing, Community Empowerment, Bangladesh, New and Traditional ICT, Local Government.

\section{Introduction}

Year after year, the global budget for information and communication technologies (ICT) penetration is increasing, with a maximisation of multi-dimensional benefits that result from the use of various ICT resources. ICT is used as a catalyst to minimise the activation time towards the community, improving individual development, and hence, strengthening community empowerment. The new ruling political party of the Bangladesh government is also committed to establish "Digital Bangladesh" by the end of 2021. With this global trend, the Bangladesh government also has been increasing its national budget on ICT year after year on the basis of the notion that it will enhance community empowerment, accelerate the establishment rate of the Millennium Development Goals, and eventually eradicate poverty. Under-developed and developing countries have been travelling the same route. Therefore it is very significant to figure out whether there is any correlation between ICT and community empowerment. The Development Research Network (D.Net) ${ }^{2}$ has started a new research

\footnotetext{
${ }^{1}$ Centre-left Awami League.

${ }^{2}$ D.Net is a premier research institution in Bangladesh which is very popular for its Pallitathya Model, a realistic telecentre paradigm that includes infomediary, info-lady and mobile-lady models.
} 
study with the title of "Community Empowerment Through ICTs: Evidence from Grassroots in Bangladesh and India" which is funded by the IdeaCorp ${ }^{3}$ and reports to the IDRC $^{4}$ over a duration of two years. This paper shows the analytical consequences, with raw research evidence which has been drawn from the benchmarking study in Bangladesh, in relation with ICT penetration, governance and community empowerment.

\section{Literature Review}

The standard of ICT governance is now an integral part of the successful operation of all organisations, whether public or private, for profit or not-for-profit, and large or small. One of its important goals is to create a common platform so that all parties understand their responsibilities and obligations [1]. Within the last decade, many public sector strategists have acknowledged the strategic value of e-technology. They also recognise the need for the improved efficiency of business processes, enhanced citizens' access to information and services, and productive relationships with citizens and private sector agencies alike. Consequently, many innovative public sector agencies worldwide (in e.g. Australia, Canada, Hong Kong, New Zealand, Singapore, the United Kingdom (UK), among many others) have had to create new ways in which to use e-business and e-service solutions ${ }^{5}$ so as to respond to the need for change [5].

Governance is a system of power within and by which organisations and other entities are controlled and directed, whereas "corporate governance" is the wealth creation and distribution system of such power. It concerns a whole host of issues surrounding and emanating from the requirement of management to ensure that an organisation or organisational units are efficient and effective in carrying out their proper functions [2, 8]. Local, regional and national governments throughout the world are attempting to broaden service delivery and citizen involvement by providing effective e-services. e-Technology has become a catalyst for enabling more effective government through better access to services and the democratic process. As public interest in the internet and e-technology solutions continues to grow, there is an increasing expectation that these solutions will be used in national and local governments for not only more efficient governance, but also to improve public access to information and services [4].

e-Government has been a priority for administration, with expectation of gains in services to citizens and performance of government processes which have acted as strong drivers for significant investments, focused managerial and political actions, and which have led to new services for corporations and citizens' live-events. These highly visible front-end interfaces require the support of effective and integrated back-office process and informed management. Therefore e-government management has to be

${ }^{3}$ IdeaCorp is an independent, non-profit organization in the Philippines that is devoted to research, training, and advocacy on development issues, particularly on the use of ICT for development (ICT4D).

4 The International Research Development Centre (IDRC) is a Canadian Crown corporation that works in close collaboration with researchers from the developing world in their search for the means to build healthier, more equitable, and more prosperous societies.

${ }^{5}$ Known as electronic or digital government. 
considered in the context of the agency's global ICT activities. The relationship between ICT use, growth stages, governance, ICT budget participation, and growth can be used as indirect and robust measures for the effectiveness of ICT governance and as indications to managers of a governance pre-condition for the generation in government [6].

At the beginning of the twenty-first century, the average number of mobile phones per 100 inhabitants in Asia, Africa, Latin America, and the Caribbean has risen by $100-400 \%$ in a span of just five years [12]. Using mobile phones was appreciated by rural communities as an easy, fast and convenient way to communicate and get prompt answers to their respective problems. Farmers were more excited about the use of the mobile phone than other forms of ICT. The governance of mobile phones to access information differed from one parish to another. Information on marketing is in high demand (100\%) [13]. Accurate and timely market information, particularly of perishable items, can reduce transaction and travel costs significantly. There have been quite a few studies that explored how mobile phones impact the livelihoods of farmers [14]. Studies by de Silva [15] and Ashraf et al. [16] assert that mobile phones can facilitate a greater export orientation in agricultural practices and marketing, potentially bringing higher incomes to rural farmers. Thus ICT penetration is not much more important than how ICT is used by the community people.

Development interventions that have evolved in response to ground requirements have been multi-stakeholder and community-led, and have pursued inclusive and participative approaches: they have been shown to be far more sustainable than others that have been imposed from above. Although these insights are well documented, they are yet to be fully integrated into many large ICT for development (ICT4D) projects and programmes these have tended to focus on the technology rather than on the capacity building and empowerment aspects of the ICT [7]. There is a reasonable volume of literature on the impact of ICT on communities $[9,11]$.

\section{Subject Matter and Conceptual Dimensions}

The project "Community Empowerment Through ICTs: Evidence from Grassroots in Bangladesh and India" is an empirical research study. This study is not related with any dimension of action research. To detect the relationship between community empowerment and ICT is the core subject matter of this research study. The impact of ICT penetration at the community level, and its relation with community empowerment, with or without precise ICT governance, is another of the study's focii. ICT governance plays an important role in establishing productive and maximum utilisation of ICT penetration. ICT penetration is not fruitful, without a proper application of ICT governance, in acting as a catalyst for community empowerment. In this study, the Union Parishad ${ }^{6}$ is considered as the community. Various types of models of ICT penetration are identified in finalising the appropriate type of community from where the final evidence would be collected to draw the most feasible study outcomes.

${ }^{6}$ The lowest government unit of Bangladesh is known as local government and governs by the Union Parishad Act 2009. 


\section{Methodology}

The entire research study is divided into two major segments. Quantitative and qualitative approaches to data collection have been used during the completed portion of the study.

The first segment consisted of a benchmarking study which was completed by January 2010. The 30 Union Parishads covered by the study have been selected by a comprehensive desk research and direct communication with different government departments, especially the Local Government and Rural Development Ministry of Bangladesh (LGRD), and the Bangladesh Telecentre Network (BTN) ${ }^{7}$ which theoretically represents a total around 4,500 Union Parishads in Bangladesh. Participatory Research Appraisal ${ }^{8}$ was the methodological research tool during the benchmarking study which consisted of four unstructured interviews ${ }^{9}$ and three focal group discussions ${ }^{10}$ including Stakeholder Mapping and ICT Mapping. During this study two local Key Informants provided intensively all kinds of local assistance to the researchers.

The second segment of the study will consist of a comprehensive survey at 12 selected Union Parishads out of the 30 Union Parishads. The survey will be conducted twice. The first survey will be completed by May 2010 and then a second survey will be completed by the beginning of 2011. During the survey periods, simultaneous Participatory Research Appraisal will also be conducted so as to draw the final outcomes.

For this paper, we have used raw evidential information from 11 Union Parishads that are involved with different models of ICT penetration. This evidence was collected using Participatory Research Appraisal during the benchmarking study.

\section{Theoretical Debate}

The depth of the relationship between community empowerment and ICT-based information systems that are available in the community is one of the key investigation agendas of this empirical research. There is no literature available to measure the community empowerment through any unique set of principle-based standards. With this apprehension, the study team revisited the theoretical underpinnings of the debate so as to understand the relationship of ICT with community empowerment. The team discussed the models offered by different stages of community empowerment through ICT which was developed by Daniel Pimienta ${ }^{11}$ [18], and the community engagement framework proposed by the Association of Ontario Health Centres [9].

7 The Bangladesh Telecentre Network (BTN) is a coalition of organisations for fostering a telecentre movement in Bangladesh.

8 Participatory Research Appraisal is distinguished at its best by the use of local graphic representations created by the community that legitimise local knowledge and promote empowerment.

9 Unstructured interviews: two unstructured interviews were with power in people and other two unstructured interviews were with people not in power.

10 Focal Group Discussion (FGD): one discussion was with a group of poor people of the community, another was with a group of non-poor people of the community; and the last was with a group of politically influential people in the community.

11 In 2008, Daniel Pimienta was the ninth Namur Award winner, an award allocated by the International Federation for Information Processing working group on social accountability and computing that is helping to organise this track. See

http://www.info.fundp.ac.be/ jbl/IFIP/winners.html/ 
The team thought that some combination of both would be explored through a new model. The new model articulates that the value of community empowerment is not only due to having access to, and utilisation of, information, rather it is directly and indirectly related with ICT. Therefore the new model has two dimensions:

- Community empowerment through access to, and utilisation of, information which is comprised of seven layers: inform, consult, involve, collaborate, partner, delegate authority, and autonomy and empowerment.

- Community empowerment through ICT which consists of six layers: access, use, technological appropriation, carrier of meaning, social appropriation and empowerment.

When a community reaches the stage of delegating authority due to access to and utilisation of all of their required multi-dimensional information through using ICT, the community crosses the stage of "carrier of meaning" and enters into the stage of "social appropriation". At the stage of social appropriation of ICT, the maximum number of community people doing daily life activities using ICT is reached. This eventually makes the community's people autonomous and then empowered. To achieve community autonomy and empowerment, the practice of using ICT at the social appropriation level is not merely related with either the level of ICT penetration or the percentage of community people who get access to ICT: rather, it is strongly associated with ICT governance. The evidence shows the ICT governance is much more fundamental than ICT penetration for community empowerment and the ethics of the various agents of ICT applications (like InfoLady ${ }^{12}$, MobileLady, Infomediary), computing, mobile usage and other resources of ICT.

\section{Local Government of Bangladesh: Status of ICT Penetration and Community Empowerment}

This section has four parts. These parts outline the basic statistics in relation to Bangladesh's local governments, ICT penetration in the Union Parishads, the status of community empowerment in the Union Parishads, and a comparative study among several of them.

\subsection{Basic Statistics of Local Government of Bangladesh}

Bangladesh's population is almost evenly distributed throughout its 64 districts except for the three Hill Tracts districts which are rather sparsely inhabited. On average, a district has a population of about 1.8 million, a Thana 230,000, a union 25,000 and a village has 2,000. There are 490 thanas, 4,451 unions and 59,990 villages. The number of households is about 20 million. On average, a household consists of 5.6 persons. There are four metropolitan cities and 119 municipalities in the country.

The level of urbanisation in Bangladesh is low at 20\%. This means that $80 \%$ of the country's total population of about 120 million lives in rural areas and depends

${ }^{12}$ An informative newspaper article on the first of these three initiatives is described by Davinder Kumar. Two-wheel triumph. The Guardian, 23 November, 2009. See http://www.guardian.co.uk/journalismcompetition/professional-two-wheel-triumph. 
primarily on a poorly developed agriculture for livelihood. The annual growth rate of the population has come down to $1.75 \%$ with the acceptance of family planning practices rising to $48.7 \%$. The sex ratio is 106 males for every 100 females. The density of population per square kilometre is 800 . Some $44.3 \%$ of the people are literate: about five million have passed secondary school level and another 1.27 million are graduates. The primary school enrollment rate has risen to $86 \%$ and the rate for secondary school enrollment to $33 \%$. According to the 2007 statistics, there are 450,000 internet users in Bangladesh ${ }^{13}$.

There are 2,165 telecentres in Bangladesh (see table 1). Among them, the Dhaka division has the highest number with 615 telecentres and Barisal has the lowest at 94 telecentres. The Local Government and Rural Development Ministry has initiated a project for infrastructural capacity-building of the Local Government Unit, the Union Parishad, in collaboration with the United Nations Development Programme (UNDP). Already 30 Union Information Centres ${ }^{14}$ have been set up, and more than 100 Union Information Centres are going to be installed in the timeline of $2010-11^{15}$.It has now been established in the mindset of national policy makers and development activities that telecentres have the highest possibility of impact in enhancing community empowerment and hence on eliminating poverty from the community.

Table 1. Division Wise Telecentre Distribution

\begin{tabular}{ll}
\hline Division of Bangladesh & Number of Telecentres \\
\hline Barisal & 94 \\
Chittagong & 495 \\
Dhaka & 615 \\
Khulna & 284 \\
Sylhet & 127 \\
Rajshahi & 549 \\
Total & 2165 \\
\hline
\end{tabular}

By the year 2020, each Union Parishad will have one Union Information Centre to ensure the access of information by citizens. Recently, the Bangladesh government has enacted four laws to strengthen the decentralisation of power and authority through local government activities. The Acts are called the Union Parishad Act 2009, Upazilla Parishad Act 2009, City Corporation Act 2009, and Paurashava Act 2009. At the same time, the Right To Information Act 2009 also came into force. There are many provisions relating to ICT among these Acts. The Bangladesh national budget of 2009-10 has also emphasised ICT investments under Private Public Partnership projects.

${ }^{13}$ Bangladesh Bureau of Statistics, http://www.bbs.gov.bd/, and local government division of Bangladesh, http://www.lgd.gov.bd/

${ }^{14}$ The Union Information Centre (UIC) is a Public-Private-People's Partnership (PPPP) model. The PPPP idea comes from the successful Community e-Centre $(\mathrm{CeC})$ experiences.

${ }^{15}$ Bangladesh Telecentre Network, http://www.mission2011.net.bd/ 


\subsection{Status of ICT Penetration in 11 Selected Union Parishads of Bangladesh}

In this research study, two types of ICT have been involved: traditional or old ICT like phone, radio, and television, and new ICT such as the computer and internet. To measure the ICT penetration level into the root community in a realistic manner, the types of ICT penetration have been detected initially in conjunction with different models of ICT penetration. The types of ICT penetration and their related models used in this research paper are discussed below:

- None: it is really very difficult to find a Union Parishad where there is no existence of traditional ICT. The evidence from the Participatory Research Appraisal shows that this presumption is correctly identified. However, there are a great number of places where there is no existence of new ICT such as computer or internet connectivity; in this study, those types of ICT penetration are considered as None).

- Only Community: there are many Union Parishads or communities where there is the presence of various types of traditional and new ICT but ICT does not exist at the local government premises. Different kinds of model of ICT penetration also have been detected: a few communities have only ICT but no telecentre, a few communities have a telecentre but no ICT, and a few communities have both a telecentre and ICT.

- Only Local Government: there are many Union Parishads or communities where there is no existence of new ICT at the community level, whereas local government possesses new ICT. Under this type of model, there are also a few local governments which have only ICT but no telecentre or Union Information Centre, a few local governments have only a telecentre but no other ICT at any branch of the office, and a few local governments have both ICT at the office as well as at the telecentre.

- Both in Local Governments and Communities: there are also a few Union Parishads where new ICT is located at both the community and the local government level including different models of ICT penetration and accessibility.

As Figure 1 shows, there are few Union Parishads where there is the presence of new ICT at local government and community level but no telecentre, a few Union Parishads have new ICT and a telecentre at the local government level and only new ICT at community level but no telecentre, and few Union Parishads have only new ICT at the local government level but no telecentre. At the community level, the presence of new ICT and a telecentre is very sound. This is the most ICT-penetrated form of community where generally all types of ICT resources are available.

The ICT penetration level has been divided into two broad categories. One is a private place of ICT penetration where only the household and individual access is guaranteed and public access is denied; the second is a public place of ICT penetration where public access is welcomed and which has more comparative impacts over the community empowerment. The evidence in Figure 1 shows that ICT penetration in 


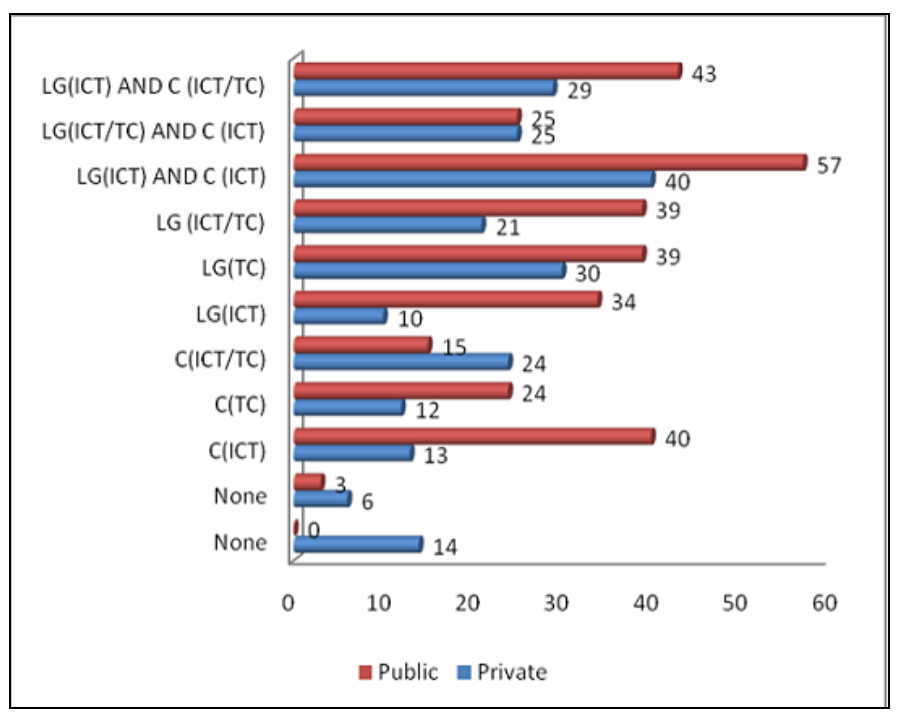

Fig. 1. ICT Penetration in 11 selected Union Parishads

public places is more than in private places. There are few Union Parishads where ICTs penetration in a public place is zero. The Union Parishads where the community has only new ICT and a telecentre have good ICT penetration. Generally, in Union Parishads, where new ICT penetration is high at both local government and community levels, new ICT penetration occurs more in the public places than private places. This indicates that new ICT are not yet cost-effective and cost-friendly for the poor citizens of Bangladesh.

Table 2 shows the ICT penetration score in Hathazari Union Parishad which is located at Chittagong division: there, possession of old ICT is remarkable. The evidence shows that $90 \%$ of households use phones whereas only $10 \%$ use the internet on their mobile. Among the public places where any person from the community has access to the ICT, $95 \%$ possess a phone but no public place uses the internet connection in it; $40 \%$ of public places use a computer whereas only $20 \%$ use internet in it.

The evidence also shows that $80 \%$ of public places use a television, which is $5 \%$ more than exists in private possession as a catalytic factor to maximise business outcomes. In this ICT penetration score, the weight of private access is given less concentration than the weight of public access. This is because private access to ICT is only concerned with individual empowerment, whereas public access to ICT is associated with community empowerment due to the accessibility of a large percentage of the population at a point that can enhance mass communication. Table 3 also shows all the scores of ICT penetration together. The status of the ICT penetration is detected by the relative scoring system: 0 to 15 indicates Low, 16 to 30 indicates Medium and above 30 indicates high status. 
Table 2. ICT Penetration Score of Hathazari Union Parishad, Chittagong, Bangladesh

\begin{tabular}{|c|c|c|c|c|c|c|}
\hline \multicolumn{7}{|c|}{ LG(ICT) AND C (ICT) : Hathazari Union Parishad, Hathazari, Chittagong } \\
\hline \multicolumn{7}{|c|}{ ICT Penetration Scoring } \\
\hline & $\begin{array}{l}\text { Private } \\
\text { Access } \\
\text { weight }\end{array}$ & $\begin{array}{l}\text { Percentage of } \\
\text { penetration at } \\
\text { household } \\
\text { level }\end{array}$ & $\begin{array}{l}\text { Weighted } \\
\text { Average }\end{array}$ & $\begin{array}{l}\text { Public } \\
\text { Access } \\
\text { Weight }\end{array}$ & $\begin{array}{l}\text { Percentage of } \\
\text { penetration } \\
\text { (public } \\
\text { places) }\end{array}$ & $\begin{array}{l}\text { Weighted } \\
\text { Average }\end{array}$ \\
\hline Radio & 10 & $60 \%$ & 6 & 10 & $80 \%$ & 8 \\
\hline Television & 20 & $75 \%$ & 15 & 20 & $80 \%$ & 16 \\
\hline $\begin{array}{c}\text { Phone } \\
\text { (without } \\
\text { Internet } \\
\text { connection) } \\
\end{array}$ & 15 & $90 \%$ & 14 & 20 & $95 \%$ & 19 \\
\hline $\begin{array}{c}\text { Computer } \\
\text { (without } \\
\text { Internet } \\
\text { connection) }\end{array}$ & 15 & $20 \%$ & 3 & 20 & $40 \%$ & 8 \\
\hline $\begin{array}{l}\text { Mobile Phone } \\
\text { (with Internet } \\
\text { connection) }\end{array}$ & 20 & $10 \%$ & 2 & 0 & $0 \%$ & 0 \\
\hline $\begin{array}{l}\text { Computer } \\
\text { (with Internet } \\
\text { connection) }\end{array}$ & 20 & $1 \%$ & 0 & 30 & $20 \%$ & 6 \\
\hline Total & 100 & & 39.7 & 100 & & 57 \\
\hline $\begin{array}{c}\text { Weight for } \\
\text { Private Access }\end{array}$ & & & $35 \%$ & & & $65 \%$ \\
\hline Overall Weight & & & 50. & & & \\
\hline
\end{tabular}

\subsection{Status of Community Empowerment in 11 Selected Union Parishads of Bangladesh}

To measure the eight components of community empowerment, questionnaires have been designed in relation with the core objectives of the research. The scoring rule for Community Empowerment is crucial to the observation of the differences of empowerment status between communities (table 3 ). The status of community empowerment in 11 of the country's Union Parishads is shown in appendix 1.A and 1.B.

Table 3. Scoring Guideline of Community Empowerment

\begin{tabular}{lc}
\hline \multicolumn{1}{c}{$\begin{array}{c}\text { Stages of Community } \\
\text { Empowerment }\end{array}$} & Scoring points \\
\hline Autonomy \& empowerment & 91 to 100 \\
Delegate Authority & 81 to 90 \\
Partner & 71 to 80 \\
Collaborate & 61 to 70 \\
Involve & 41 to 60 \\
Consult & 21 to 40 \\
Inform & 1 to 20 \\
\hline
\end{tabular}


Seven stages of community empowerment are totally absent. Those components are described below in brief:

- Participatory Democracy Vs ICT: is intended to measure the appreciation level of participatory democracy in the community and the impact of ICT over it. Appendix 1.A and 1.B show Fathepur Union Parishad, where local government has new ICT and the community has new ICT as well as a telecentre. PurbaCharbata Union Parishad (where local government has new ICT including a telecentre but there is no existence of new ICT at the community level) has the highest score of 35. This indicates that both Union Parishads are at the "Consult" stage of community empowerment.

- Rights-based Knowledge Vs ICT: is intended to measure the people's knowledge of their entitlements and the exercise of their rights, and the role of ICT over this. Hathazari Union Parishad ${ }^{16}$, where local government and the community both have new ICT, scored 45: this expresses the "Involve" stage of community empowerment. Balukhali Union Parishad, where there is no presence of new ICT, scored only 20 which indicates the "Inform" stage of community empowerment.

- Social Violation Vs ICT: is intended to identify the depth of social violation and how ICT affects these issues. Kohalong Union Parishad, where there is no new ICT, has scored only 15 . This means that this community is still at the "Inform" stage of community empowerment. PurbaBirgong Union Parishad, where there is no presence of new ICT but there is a telecentre in the community and no ICT at the local government level, scored 30. Two other locations where ICT penetration is high at both the community and the local government level - like the Hathazari Union Parishad and the Shapara Union Parishad - indicate that they are at the "Consult" stage of community empowerment.

- Community Involvement Vs ICT: is intended to measure the community involvement in the roles and responsibilities of the local government and the role of ICT in this. The Nila Union Parishad, where only the community has new ICT, has a score of 25 which indicates the "Consult" stage of community empowerment. It therefore has the same status as the Shapara Union Parishad which is a highly ICT-penetrated community at both the community and local government premises.

- Knowledge of Community Vs ICT: to measure the level of the knowledge of the community people about the local, national and international issues and the role of ICT in this. Kohalong Union Parishad, with a very low level of ICT penetration, has scored 35: this indicates a "Consult" stage of community empowerment. The Shapara Union Parishad, with a high ICT penetration, has scored below the Kohalong Union Parishad .The Hathazari Union Parishad, with the highest ICT penetration, has the same empowerment status as Kohalong Union Parishad.

${ }^{16}$ This is the place where of the first Micro Credit revolution started under the initiative of $\mathrm{Mu}$ hammed Yunus. More than $80 \%$ of women from the poor community are involved in it. There is also evidence that women obtain Micro Credit to start computer shops in public places where people can use computers in the presence of other family members in a group. 
- Resource Mobilization Vs ICT: to measure the community involvement towards the annual activity plan and resource mobilisation plan of the Local government and the role of ICT in it. A highly ICT-penetrated area like Shapara Union Parishad has the same status of empowerment as a poorly ICT-penetrated area like Joyga Union Parishad.

- Good Governance Vs ICT: to measure the transparency and accountability of Local Government towards the community and the role of ICT in it. A highly ICT-penetrated Union Parishad, like Hathazari, has the same status of empowerment as a poorly ICT-penetrated area, like Nila Union Parishad.

- Public and Private Collaboration Vs ICT: to measure the presence of the collaboration between the local government institution and local community organisation regarding access to information through ICT. Basically this indicator focuses on the presence of the telecentre. If a telecentre exists in the local government, the indicator assumes that it can have the highest impact over empowerment due to the people of the Union Parishad having mass access to their required information easily and in a friendly environment; therefore its weight is the highest at 80 . Only two Union Parishads have a telecentre that maximises the e-services to the citizens of the community. If the telecentre exists in the community only, it presumes that it also has impact over community empowerment, but the impact is not higher than that of the local government telecentre due to public accessibility and cost efficiency.

\subsection{Comparative Study of Status of Community Empowerment in 11 Selected Union Parishads of Bangladesh}

This last section explores a number of basic comparisons among Union Parishads and the need for proper ICT governance.

\subsubsection{Basic Comparisons}

Early evidence collected during the benchmarking study produced the following general outcomes (which are outlined in Appendix 2):

- Where ICT penetration is low, the overall status of empowerment is at the "Inform" stage.

- Where ICT penetration is only at the community level, the overall status of the empowerment is at the "Consult" stage.

- Where the ICT penetration level is only at the local government, and there is no presence of new ICT at the community level, the overall status of empowerment is at the "Consult" level like the overall empowerment status of an ICT-penetrated community. One exception is the Purba Charbata Union Parishad where the overall empowerment status is at the "Involve" stage.

- Where ICT penetration level is high at both local government and community level, the overall community empowerment is at the "Consult" level like the empowerment status of an ICT-penetrated local government and community separately. 


\subsubsection{Need to Apply Proper ICT Governance}

Evidence shows that the level of ICT penetration is not proportionally related to community empowerment. High ICT-penetrated Union Parishads do not have a higher status of empowerment. With either community or local governmentpenetrated levels, a Union Parishad has the same empowerment status as a highpenetrated area. At the same time, evidence indicates that traditional ICT-penetrated Union Parishads have a lower status of empowerment.

In comparison with other ICT-penetrated Union Parishads, ICT has a very positive impact on overall empowerment status. During the benchmarking study, it has also been noted that ICT-penetrated areas have been facing very serious crises due to them not having applied proper ICT governance. In the maximum ICT-penetrated areas, there are many traditional and new ICT resources but none where there is a proper application of ICT governance.

\section{Findings}

Early findings from the benchmarking study are outlined below:

- In the Participatory Democracy Vs ICT component of the empowerment measurement, it is noticed that people highly appreciated ICT over the dialogue correspondence of elections. Figure 2 (which follows) shows that this applies to $20 \%$ people in Hathazari, which is a highly ICT-penetrated Union Parishad; the lowest score is $1.5 \%$ at Kohalong, which is most poorly ICT-penetrated Union Parishad. It also is also important to note that an informed decision-making process, sound pluralism, and other important features of participatory democracy, is not yet exercised through ICT. No single Union Parishad informs its final decisions through ICT.

- In the Good Governance Vs ICTs component of community empowerment, evidence shows that only $7 \%$ of people are being informed about the annual budget of the local government in Joyga Union Parishad, which is the only community to have new ICT and a telecentre. In BaluKhali Union Parishad only $0.5 \%$ of people are being informed about annual plan of the local government: in this Union Parishad, there is no presence of new ICT either at local government of community levels. It is also very important to note the percentage of people who use ICT to correspond about the annual budget of the local government, a maximum proportion of them are related with the leading political party. Therefore, this is potentially a threat to community empowerment.

- In the Community Involvement Vs ICT component of the community empowerment measurement, evidence shows that only $3 \%$ people in Kholang Union Parishad, where there is no presence of new ICT and a telecentre, use ICT to know about the Social Safety Net Programme, which is run by the local government and is a part of Annual Development Programme nationwide. In Hathazari Union Parishad, 5\% of people correspond about the Social Safety Net Programme through ICT. The alarming point is that only those people who are directly and indirectly related with the leading political party use ICT to have communication on the Social Safety Net Programme. 


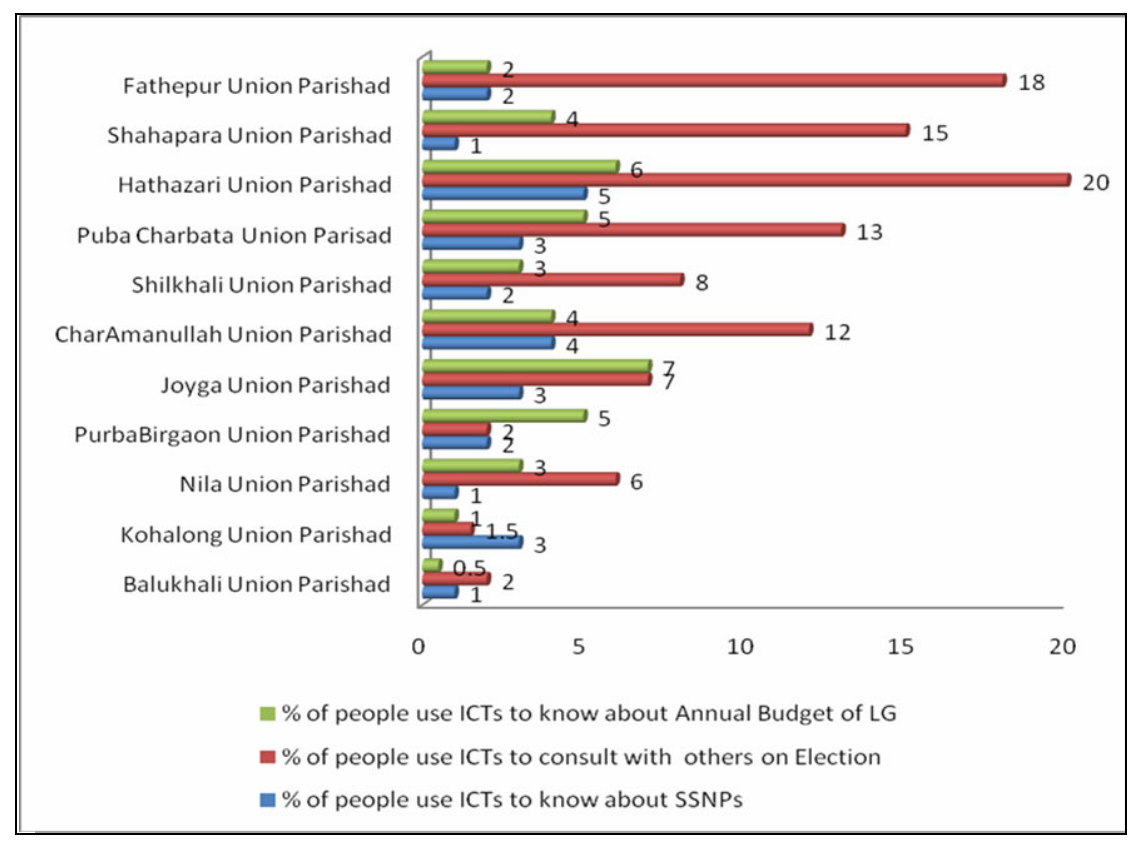

Fig. 2. ICT penetration and its role over community

- Where there is a telecentre, the following problems are detected from voices at the grassroots:

o The local non-government organisations use the telecentre to promote their activities towards the national and international funding organisations.

○ Infomediary or Mobile-Lady or Info-Lady does not work due to a lack of financial supply.

- ICT Governance for the telecentre is not maintained by the Infomediary or Mobile-Lady or Info-Lady. In a few cases, ICT Governance for the telecentre is not realistic enough to influence the work of the Infomediary.

- In general, around $85 \%$ of people inclusively use traditional ICT to communicate with their relatives, and to maintain domestic relationships. More than $90 \%$ of political people use traditional ICT to gain their personal political goals, and around $90 \%$ of businesses use traditional ICT to maintain their business activities.

- Evidence from the benchmarking study shows that there is a good relationship between ICT penetration and ICT governance towards the community empowerment. Table 4 shows that where ICT penetration and ICT governance is high, the status of community empowerment is high. Where ICT penetration and ICT governance is low, the status of community empowerment is low. The evidence directly shows that community empowerment is more related with ICT governance rather than ICT penetration. 
Table 4. ICT Penetration, Governance and Community Empowerment

\begin{tabular}{lll}
\hline ICT Penetration & ICT Governance & Community Empowerment \\
\hline High & High & High \\
High & Low & Low \\
Low & Low & Low \\
Low & High & High \\
\hline
\end{tabular}

- There is also evidence of a strong link between the ethics of computing and ICT penetration towards community empowerment. Table 5 (below) shows that, if ICT penetration and ethics of computing is high, the community has a raised level of empowerment. If ICT penetration and the ethics of computing is low then the community has a low status of empowerment. If ICT penetration is low but ethics of computing is high, then the community has the status of raising empowerment.

- In the case of the Union Information Centre, there is no presence of ICT governance. It may be there on paper, but not in application.

Table 5. ICT Penetration, Ethics of computing and Community Empowerment

\begin{tabular}{lll}
\hline ICT Penetration & Ethics of Computing & Community Empowerment \\
\hline High & High & Raised Empowerment \\
High & Low & Disempowerment \\
Low & Low & Low Empowerment \\
Low & High & Raising Empowerment \\
\hline
\end{tabular}

\section{Conclusions}

Evidence from the benchmarking study initially shows why ICT governance and the ethics of computing are necessary to functionalise ICT penetration effectively and efficiently towards community empowerment. Observations include the a) lack of establishment of having clearly understood responsibilities for ICT at all levels; b) lack of having a plan to best support the local government and telecentre where, organisationally, ICT penetration is high; c) lack of acquiring ICT validly through evaluating the risks of the investment, making sure that it adds value, and monitoring the extent to which it performs as proposed; d) lack of the quality of ICT required to supply adequate data quality, security, privacy; e) lack of ICT performance when it is required; f) lack of usage of ICT without disrespecting human factors; g) lack of measurement of status of the ethics of computing as well as mobile usage. All these limitations show the lack of efficient ICT governance and the establishment of an ethics of computing and mobile usage. The evidence also shows that when ICT penetration is high, but with a low level of application of ICT governance, the status of empowerment is lower. When ICT penetration is high with a high level of application of ICT governance, the status of empowerment is higher. 


\section{References}

1. Feld, C.S., Stoddard, D.B.: Fixing the Corporation-IT. In: Disconnect, Working Knowledge, Harvard Business School Newsletter, Harvard Management Communication letter (Online): A Newsletter from Harvard Business School Publishing. Harvard Business School Publishing, Boston

2. Ziolkowski, R., Clark, E.: Standards of ICT Governance: The Need for Stronger Epistemological Foundations in Shifting Sands. The Asia Pacific Journal of Public Administration 26(1), 77-90 (2005)

3. Taifur, S., Chowdhury, M.: Problems of E-Governance in Bangladesh and Possible Steps Towards Solutions. In: Seminar Paper: Road Map for ICT Development in Bangladesh, IDB Bhaban (2003)

4. Asgarkhani, M.: The Effectiveness of e-Service in Local Government: A Case Study. The Electronic Journal of e-Government 3(4), 157-166 (2005), http : / / www . ej eg . com

5. Heeks, R.: Software Strategies in Developing Countries. Development Informatics Working Paper Series, Paper No. 6. Institute for Development Policy and Management (June 1999)

6. Reinhard, N., Sun, V., Meizi, R.: ICT Spending and Governance in Brazilian Public Administration. In: 19th Bled eConference, Slovenia (2006)

7. Gurumurthy, A.: Promoting gender equality? Some development-related uses of ICTs by women, Development in Practice (2006)

8. Mingers, J., Wilkocks, L. (eds.): Social Theory and Philosophy for Information Systems. John Wiley \& Sons, West Sussex (2004)

9. AOCH: A Review of the Trends and Benefits of Community Engagement and Local Community Governance in Health Care, prepared by Ktpatzer Consulting, Community Centered Primary Health Care, Ontario, Canada (2006)

10. Khelladi, Y.: The Infocentros Telecentre Model. World Resources Institute, Washington (2001)

11. Raihan, A., Mahmud, H., Uddin, F., Billah, M., Das, N., Sarker, T.: Pallitathya: An Information and Knowledge System for the Poor and Marginalized Experience from Grassroots in Bangladesh, D.Net, Dhaka (2007)

12. Orbicom: Emerging Development Opportunities: The Making of Information Societies and ICT Markets. IDRC, Ottawa (2007)

13. Masuki, K.F.G., Kamugisha, R., Mowo, J.G., Tanui, J., Tukahirwa, J., Mogoi, J., Adera, E.O.: Role of mobile phones in improving communication and information delivery for agricultural development: Lessons from South Western Uganda. In: Workshop at Makerere University, Uganda, March 22-23 (2010)

14. Rashid, A.T., Elder, L.: Mobile Phones and Development: An Analysis of IDARCSupported Projects. The Electronic Journal on Information Systems in Developing Countries (EJISDC) 36(2), 1-16 (2009)

15. De Silva, H.: Using ICTs to Create Efficiencies in Agricultural Markets: Some Findings from Sri Lanka. Paper Presented to IDRC, Ottawa (2008)

16. Ashraf, N., Gine, X., Karlan, D.: Growing Export Oriented Crops in Kenya: An Evaluation of DrumNet Services. IDRC, Ottawa (2005)

17. CEMP Project (Community Empowerment through ICTs: Grassroots Evidence from Bangladesh and India), D.Net (Development Research Network), Bangladesh (2009-2010)

18. Pimienta, D.: Linguistic Diversity in Cyberspace - Models for Development and Measurement. In: Measuring Linguistic Diversity on the Internet, UNESCO, Paris (2005) 


\section{Appendix 1.A: Status of Community Empowerment}

\begin{tabular}{|c|c|c|c|c|c|}
\hline Model & LG(TC) & $\begin{array}{c}\text { LG } \\
(\text { ICT/TC) }\end{array}$ & $\begin{array}{c}\text { LG(ICT) } \\
\text { AND C } \\
\text { (ICT) }\end{array}$ & $\begin{array}{l}\text { LG(ICT/TC) } \\
\text { AND C (ICT) }\end{array}$ & $\begin{array}{c}\text { LG(ICT) AND } \\
\text { C (ICT/TC) }\end{array}$ \\
\hline $\begin{array}{l}\text { Name of the } \\
\text { PRA } \\
\text { component }\end{array}$ & $\begin{array}{c}\text { Shilkhali } \\
\text { UP, Cox's } \\
\text { Bazar }\end{array}$ & $\begin{array}{c}\text { Puba } \\
\text { Charbata } \\
\text { UP, Noakhali }\end{array}$ & $\begin{array}{c}\text { Hathazari } \\
\text { UP, } \\
\text { Chittagogn }\end{array}$ & $\begin{array}{l}\text { Shahapara UP, } \\
\text { Gaibandha }\end{array}$ & $\begin{array}{c}\text { Fathepur UP, } \\
\text { Jhenaidha }\end{array}$ \\
\hline $\begin{array}{l}\text { Participatory } \\
\text { Democracy } \\
\text { Vs ICT }\end{array}$ & 30 & 35.00 & 30 & 28 & 35 \\
\hline $\begin{array}{l}\text { Rights-based } \\
\text { Knowledge } \\
\text { Vs ICT }\end{array}$ & 25 & 30.00 & 45 & 26 & 41 \\
\hline $\begin{array}{l}\text { Social Viola- } \\
\text { tion Vs ICT }\end{array}$ & 30 & 50.00 & 30 & 30 & 40 \\
\hline $\begin{array}{c}\text { Community } \\
\text { Involvement } \\
\text { Vs ICT } \\
\end{array}$ & 20 & 50.00 & 35 & 24 & 35 \\
\hline $\begin{array}{l}\text { Knowledge } \\
\text { of Commu- } \\
\text { nity Vs ICT }\end{array}$ & 30 & 30.00 & 35 & 30 & 50 \\
\hline $\begin{array}{c}\text { Resource } \\
\text { Mobilization } \\
\text { Vs ICT } \\
\end{array}$ & 20 & 45.00 & 30 & 26 & 30 \\
\hline $\begin{array}{c}\text { Good } \\
\text { Governance } \\
\text { Vs ICT } \\
\end{array}$ & 10 & 25.00 & 25 & 20 & 25 \\
\hline $\begin{array}{l}\text { Public and } \\
\text { Private } \\
\text { Collabora- } \\
\text { tion Vs ICT }\end{array}$ & 80 & 80.00 & 0 & 80 & 50 \\
\hline Total Score & 245 & 345.00 & 230 & 264 & 306 \\
\hline $\begin{array}{l}\text { Average } \\
\text { Score }\end{array}$ & 30.625 & 43.125 & 28.75 & 33 & 38.25 \\
\hline $\begin{array}{l}\text { Empower- } \\
\text { ment Level }\end{array}$ & Medium & Medium & Low & Medium & Medium \\
\hline
\end{tabular}

Source: D.Net [17]. 


\section{Appendix 1.B: Status of Community Empowerment}

\begin{tabular}{|c|c|c|c|c|c|c|}
\hline Model & None & None & C(ICT) & C(TC) & $\begin{array}{c}\text { C(ICT/T } \\
\text { C) }\end{array}$ & LG(ICT) \\
\hline $\begin{array}{l}\text { Name of the } \\
\text { PRA } \\
\text { component }\end{array}$ & $\begin{array}{c}\text { Kohalong } \\
\text { UP, } \\
\text { Bandarban }\end{array}$ & $\begin{array}{c}\text { Balukhali } \\
\text { UP, } \\
\text { Rangamati }\end{array}$ & $\begin{array}{c}\text { Nila UP, } \\
\text { Cox } \\
\text { Bazar }\end{array}$ & $\begin{array}{c}\text { PurbaBirgaon } \\
\text { UP, Daskhin } \\
\text { Sunamgonj }\end{array}$ & $\begin{array}{c}\text { Joyga } \\
\text { UP, } \\
\text { Noakhali }\end{array}$ & $\begin{array}{c}\text { CharAm } \\
\text { anullah } \\
\text { UP, } \\
\text { Noakhali } \\
\end{array}$ \\
\hline $\begin{array}{l}\text { Participatory } \\
\text { Democracy } \\
\text { Vs ICT }\end{array}$ & 20 & 15 & 30 & 25 & 32 & 25.00 \\
\hline $\begin{array}{l}\text { Rights-based } \\
\text { Knowledge } \\
\text { Vs ICT }\end{array}$ & 30 & 20 & 25 & 30 & 30 & 30.00 \\
\hline $\begin{array}{c}\text { Social } \\
\text { Violation Vs } \\
\text { ICT } \\
\end{array}$ & 15 & 10 & 20 & 30 & 35 & 25.00 \\
\hline $\begin{array}{c}\text { Community } \\
\text { Involvement } \\
\text { Vs ICT } \\
\end{array}$ & 15 & 10 & 25 & 25 & 32 & 20.00 \\
\hline $\begin{array}{c}\text { Knowledge } \\
\text { of } \\
\text { Community } \\
\text { Vs ICT }\end{array}$ & 35 & 25 & 50 & 20 & 35 & 25.00 \\
\hline $\begin{array}{c}\text { Resource } \\
\text { Mobilization } \\
\text { Vs ICT } \\
\end{array}$ & 15 & 15 & 25 & 25 & 25 & 20.00 \\
\hline $\begin{array}{c}\text { Good } \\
\text { Governance } \\
\text { Vs ICT }\end{array}$ & 15 & 15 & 25 & 20 & 34 & 25.00 \\
\hline $\begin{array}{l}\text { Public and } \\
\text { Private } \\
\text { Collabora- } \\
\text { tion Vs ICT }\end{array}$ & 0 & 0 & 0 & 50 & 50 & 0.00 \\
\hline Total Score & 145 & 110 & 200 & 225 & 273 & 170.00 \\
\hline $\begin{array}{l}\text { Average } \\
\text { Score }\end{array}$ & 18.125 & 13.75 & 25 & 28.125 & 34.125 & 21.25 \\
\hline $\begin{array}{l}\text { Empower- } \\
\text { ment Level }\end{array}$ & Low & Low & Low & Low & Medium & Low \\
\hline
\end{tabular}

Source: D.Net [17]. 


\section{Appendix 2: ICT Penetration and Empowerment Status}

\begin{tabular}{|c|c|c|c|c|c|c|c|c|}
\hline $\begin{array}{c}\text { Type of } \\
\text { ICT } \\
\text { penetration }\end{array}$ & $\begin{array}{l}\text { Model of } \\
\text { ICT }\end{array}$ & $\begin{array}{l}\text { Location of } \\
\text { PRA }\end{array}$ & 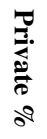 & $\begin{array}{l}\frac{\sigma}{\sigma} \\
\bar{\Xi} \\
\partial^{9}\end{array}$ & 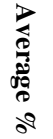 & Status & 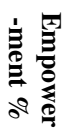 & Status \\
\hline \multirow{2}{*}{ None } & \multirow{2}{*}{ None } & $\begin{array}{c}\text { Balukhali UP, } \\
\text { Rangamati }\end{array}$ & 14 & 0 & 5 & Low & 14 & Low \\
\hline & & $\begin{array}{c}\text { Kohalong UP, } \\
\text { Bandarban }\end{array}$ & 6 & 3 & 4 & Low & 18 & Low \\
\hline \multirow{3}{*}{ Community } & C(ICT) & $\begin{array}{c}\text { Nila UP, Cox } \\
\text { Bazar }\end{array}$ & 13 & 40 & 30 & Low & 25 & Low \\
\hline & C(TC) & $\begin{array}{l}\text { PurbaBirgaon } \\
\text { UP, Daskhin } \\
\text { Sunamgonj }\end{array}$ & 12 & 24 & 20 & Low & 28 & Low \\
\hline & C(ICT/TC) & $\begin{array}{c}\text { Joyga UP, } \\
\text { Noakhali } \\
\end{array}$ & 24 & 15 & 18 & Low & 34 & Medium \\
\hline \multirow{3}{*}{ LG } & LG(ICT) & $\begin{array}{c}\text { CharAmanullah } \\
\text { UP, Noakhali }\end{array}$ & 10 & 34 & 26 & Low & 21 & Low \\
\hline & $\begin{array}{c}\text { LG } \\
(\mathrm{ICT} / \mathrm{TC})\end{array}$ & $\begin{array}{c}7 \text { no Puba } \\
\text { Charbata UP, } \\
\text { Noakhali } \\
\end{array}$ & 21 & 39 & 33 & Medium & 43 & Medium \\
\hline & LG(TC) & $\begin{array}{c}\text { Shilkhali UP, } \\
\text { Cox's Bazar }\end{array}$ & 30 & 39 & 36 & Medium & 31 & Medium \\
\hline \multirow{3}{*}{$\begin{array}{c}\text { LG and } \\
\text { Community }\end{array}$} & $\begin{array}{c}\text { LG(ICT) } \\
\text { AND C } \\
\text { (ICT) }\end{array}$ & $\begin{array}{l}\text { Hathazari UP, } \\
\text { Chittagogn }\end{array}$ & 40 & 57 & 51 & Medium & 29 & Low \\
\hline & $\begin{array}{l}\mathrm{LG}(\mathrm{ICT} / \mathrm{T} \\
\mathrm{C}) \text { AND C } \\
\text { (ICT) }\end{array}$ & $\begin{array}{c}\text { Shahapara UP, } \\
\text { Gaibandha }\end{array}$ & 25 & 25 & 25 & Low & 33 & Medium \\
\hline & $\begin{array}{c}\text { LG(ICT) } \\
\text { AND C } \\
\text { (ICT/TC) }\end{array}$ & $\begin{array}{l}\text { Fathepur UP, } \\
\text { Jhenaidha }\end{array}$ & 29 & 43 & 38 & Medium & 38 & Medium \\
\hline
\end{tabular}

Source: D.Net [17]. 